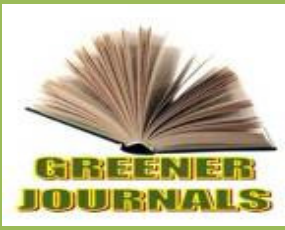

\title{
The Evaluation of Concentrate and Forage Combination on the Performance and Litter Weight of New Zealand Rabbit
}

\section{Monica Ogochukwu Ironkwe and *Anthonia ljeoma Ukanwoko}

Department of Animal Science, University of Port Harcourt. P. M. B. 5323 Choba, Port Harcourt, Rivers State, Nigeria.

\section{ARTICLE INFO}

Article No.: 102616172

DOI: 10.15580/GJAS.2016.10.102616172

Submitted: $26 / 10 / 2016$

Accepted: $31 / 10 / 2016$

Published: 18/11/2016

${ }^{*}$ Corresponding Author

Anthonia ljeoma Ukanwoko

E-mail: ndutonia@yahoo.com

\section{Keywords:}

Body weight gain, feed conversion ratio, final weight, litter size at birth, litter size at weaning

\section{ABSTRACT}

Twenty sexually matured New Zealand white rabbits were used to study the effect of concentrate and forage (Calopogonium mucunoides and Panicum maximum) combination on the productive and reproductive performance of the rabbits. The treatments comprised the following concentrate and forage combinations (\%): $A=$ $100: 0, B=50: 50, C=25: 75$ and $D=0: 100$. The sixteen does were randomly allotted to the four treatment diets in a Completely randomized design. The does were housed singly, served with feed twice daily and portable water provided ad libitum. Results showed significant $(P<0.05)$ differences in the final weight, body weight gain, daily feed intake, feed conversion ratio and feed cost of the treatment diets. Final weight was $3075.0 \mathrm{~g}$ for does on diet A, $2943.75 \mathrm{~g}$ for does on diet B, $2875.0 \mathrm{~g}$ and $2887.5 \mathrm{~g}$ for does on diets $C$ and $D$ respectively. Daily feed intake was highest for does on diet $D(500.9 \mathrm{~g})$ and the least for does on diet $A(88.32 \mathrm{~g})$. Diet $A$ had the best feed conversion ratio (0.84), followed by diets $B(2.41), C(3.29)$ and $D$ (6.93). Cost of feed was highest in diet A (N2077.6) and was decreasing as the percentage of forage in the diets increased. There were also significant $(P<0.05)$ differences in the litter size at birth and weaning, average litter weight at birth and weaning. Litter size at birth and weaning were $6.75,6.72 ; 7.75,7.75 ; 7.25,7.21$ and $5.75,5.69$ for diets A, B, C and D respectively. Diet B proved superior and hence recommended. 


\section{INTRODUCTION}

Nigeria like many other developing countries of the world has a protein deficiency gap, especially that of high animal protein. Rabbits will bridge the protein deficiency gap created by the protein inadequacy of traditional livestock (Iheukwumere and Okoli, 2002). Rabbits can be raised on cheap and readily available forages (Linga and Lukefahr, 2000) because they have been reported to utilize fibrous feeds efficiently (Leng, 2006). They have short gestation length, short generation interval, early sexual maturity and high prolificacy (Effiong and Wogar, 2007; Adeyemo et al., 2013). Rabbits are efficient converters of feed to flesh (Adeyemo et al., 2014)

Yusuf et al. (2010) recommended $16 \%$ crude protein and $12-15 \%$ crude fibre diet for rabbits. This can be met by feeding rabbits with concentrate and or forage. Panicum maximum (Abu et al., 2008) and Calopogonium mucunoides (Nwagu et al., 2010) have been reported to be acceptable to rabbits. Though rabbits have been found to perform best on concentrate (Farinu, 1994), the high cost of grains has caused animal scientists to shift to forages which are cheap and available.

This study was therefore aimed at evaluating the effect of concentrate and forage combination on the performance and litter weight of New Zealand rabbit.

\section{MATERIALS AND METHODS}

\section{Location of the study}

This experiment was carried out in the Rabbitry unit University of Port Harcourt Research and Demonstration Farm, Choba, Obio/Akpor Local Government Area of Rivers State in the South-South zone of Nigeria. It falls within the humid rain forest zone of West Africa with long duration of rainfall (March - November) and a very short dry season precipitation occurs during September with an average of $367 \mathrm{~mm}$ of rain in 182 rain days with a temperature range of $25-28^{\circ} \mathrm{C}$ and a very high relative humidity (above $80 \%$ rainfall (March-November) and a very short dry season precipitation occurs during September with an average of $367 \mathrm{~mm}$ of rain in 182 rain days with a temperature range of $25-28^{\circ} \mathrm{C}$ and a very high relative humidity (above $80 \%$ ).

\section{Experimental diet and design}

The fresh forages (Panicum maximum and Calopogonium mucunoides) were harvested daily within the vicinity of the experimental site. The harvested forages were rinsed with water, chopped and air - dried before being fed to the experimental animals. The concentrate ration (commercial grower's mash) was purchased in Port Harcourt, Rivers State, Nigeria. Twenty sexually matured rabbits (four bucks and sixteen does) were used. The sixteen does were randomly allotted to four treatment diets in a completely randomized design with four replicates. The four treatment diets (A, B, C and D) were formulated as follows;

Diet $A=100: 0(\%)$, Diet $B=50: 50(\%)$, Diet $C=$ $25: 75(\%)$, Diet $D=0: 100(\%)$. The experiment lasted for 10 weeks.

\section{Experimental animals and management}

The rabbits were housed singly in all - wire cages, which were designed for easy collection of animal for weighing and easy cleaning of waste. They were provided with water ad libitum while feed was served twice daily. Feed offered and the left over were weighed to determine feed intake of the animals. After the initial weight, weekly weights were also taken.

Each doe was weighed before mating with the aid of a HANA power scale with a sensitivity of $0.025 \mathrm{~g}$ to know the initial weight and they were weighed after mating until kindling. After kindling, the bunnies were also weighed weekly until weaning. Variables used to measure reproductive parameters were conception rate, gestation length, litter size, litter weight, pseudo pregnancy, weaning weight, mortality.

\section{Statistical analysis}

Data collected were subjected to a statistical analysis using SSPS (2008).

\section{RESULTS AND DISCUSSION}

The proximate composition of the concentrate and forages used in this study is shown in Table 1. Apart from the crude protein of the Panicum maximum $(10.5 \%)$, that of concentrate $(22.85 \%)$ and Calopogonium mucunoides (22.03\%) compares favourably with the $16 \%$ Crude Protein requirement recommended for rabbits (Yusuf et al., 2010). The crude fibre contents of Calopogonium mucunoides (21.73\%) and Panicum maximum (30.40\%) are higher than the range of $12-15 \%$ crude fibre recommended for rabbits (Yusuf et al., 2010). 
Table 1: Proximate composition of concentrate and forages fed to the does

\begin{tabular}{lccc}
\hline Nutrients (\%) & Concentrate & Calopogonium mucunoides & Panicum maximum \\
\hline Dry matter & 95.56 & 87.62 & 37.0 \\
Ash & 6.54 & 7.1 & 7.5 \\
Ether extract & 13.15 & 3.79 & 2.5 \\
Crude fibre & 9.18 & 21.73 & 30.4 \\
Crude protein & 22.85 & 22.03 & 10.5 \\
Nitrogen free extract & 47.63 & 45.30 & 48.7 \\
\hline
\end{tabular}

Source: Naginene and Abdallah, 1992.

The effect of the treatment on the performance of the test animals is presented in Table 2. There were significant $(P<0.05)$ differences in the final weight of the rabbits. The highest final weight was recorded in animals on diet $\mathrm{A}(3075.00 \mathrm{~g})$, the $100 \%$ concentrate diet and tended to decrease as the percentage of forage in the diet increases. Animals on diet B had a final weight of 2943.75g; this was followed by animals on diet C $(2875.00 \mathrm{~g})$ and those on diet $\mathrm{D}(2887.50 \mathrm{~g})$. This report is in contrast with Adeyemo et al (2014) but agrees with Ukpe et al (2009) and Oloruntola et al (2015). Significant $(P<0.05)$ differences existed in the body weight gain of animals on the experimental diets. The highest was in animals on Diet A (1000.00g), followed by those on diet $B(793.75 \mathrm{~g})$ being same $(P>0.05)$ with those on diet $C$ $(765.25 \mathrm{~g})$ and the least was in those on diet $D$
$(512.50 \mathrm{~g})$. There were significant $(P<0.05)$ differences in the daily feed intake of the rabbits on the experimental diets. The highest was in animals on diet $D(500.9 \mathrm{~g})$, followed by those on diets C (385.71g) and B (329.71g) with the least in those on diet A (88.32g). Daily feed intake tended to be increasing as the percentage of forage was increasing. This is in agreement with Adeyemo et al (2013). There were also significant $(P<0.05)$ differences in the feed conversion ratio. The least was in animals on diet $A(0.84)$, followed by those on diets $B(2.41)$ and $C$ (3.29) with the least in those that fed diet $D(6.93)$. Significant $(P<0.05)$ differences existed in the feed cost. The least was in diet $D(N 0.0)$, followed by diet $C$ (N588.0); diet $B$ (N1152.2) with the highest in diet A (N2077.6). This result agrees with Adeyemo et al (2013).

Table 2: Performance parameters of the does on the experimental diets

\begin{tabular}{lccccc}
\hline Parameters & A (100:0) & $\begin{array}{c}\text { Diets } \\
\text { B (50:50) }\end{array}$ & C (25:75) & D (0:100) & SEM \\
\hline Initial weight $(\mathrm{g})$ & 2075 & 2150 & 2118.75 & 2375.00 & 0.50 \\
Final weight $(\mathrm{g})$ & $3075^{\mathrm{a}}$ & $2943.75^{\mathrm{b}}$ & $2875.0^{\mathrm{c}}$ & $2887.5^{\mathrm{c}}$ & 15.14 \\
Body weight gain $(\mathrm{g})$ & $1000^{\mathrm{a}}$ & $793.75^{\mathrm{b}}$ & $765.25^{\mathrm{b}}$ & $512.5^{\mathrm{c}}$ & 32.18 \\
Daily feed intake $(\mathrm{g})$ & $88.32^{\mathrm{c}}$ & $329.71^{\mathrm{b}}$ & $385.71^{\mathrm{b}}$ & $500.9^{\mathrm{a}}$ & 57.06 \\
Average feed intake $(\mathrm{g})$ & $839.22^{\mathrm{d}}$ & $1909.47^{\mathrm{c}}$ & $2517.68^{\mathrm{b}}$ & $3554.53^{\mathrm{a}}$ & 50.53 \\
Feed conversion ratio & $0.84^{\mathrm{c}}$ & $2.41^{\mathrm{b}}$ & $3.29^{\mathrm{b}}$ & $6.93^{\mathrm{a}}$ & 1.15 \\
Feed cost (N) & $2077.6^{\mathrm{a}}$ & $1152.2^{\mathrm{b}}$ & $588.0^{\mathrm{c}}$ & $0.0^{\mathrm{d}}$ & 24.20 \\
\hline
\end{tabular}

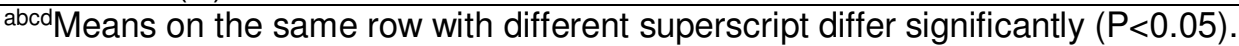

The effect of the treatment on the reproductive parameters of the test rabbits is presented in Table 3. Significant $(P<0.05)$ differences existed in the litter size at birth of the does. The highest was for does on diet $\mathrm{B}$ $(7.75 \pm 0.48)$, followed by those on diets $C(7.25 \pm 0.48)$ and $\bar{A}(6.75 \pm 0.48)$ and the least for those on diet $D$ $(5.75 \pm 0.48)$. The litter size range of $5.75-7.75$ in this study compares favourably with the litter size range of $5.67-7.00$ reported by Ezea et al (2015) but higher than the litter sizes of 4.24 and $4.20-5.00$ reported by Marykutty and Nandakumar (2000) and lyeghe Erakpotobor et al (2008) respectively. There were significant $(\mathrm{P}<0.05)$ differences in the average litter weight at birth. Average litter weight at birth tended to follow the same trend as litter size at birth. The highest was recorded for does on diet $B(57.5 \pm 2.5 \mathrm{~g})$, followed by those on diet $C(55.0 \pm 2.04 \mathrm{~g})$, diet $A(50.0 \pm 3.54 \mathrm{~g})$ and diet $D(47.5 \pm 1.44 \mathrm{~g})$. There were significant $(P<0.05)$ differences in the litter size at weaning. Does on diet $B$ $(7.75 \pm 0.48)$ recorded the highest, this is followed by does on diet $C(7.21 \pm 0.29)$, diet $A(6.72 \pm 0.63)$ with the least for does on diet $D(5.69 \pm 1.44)$. The litter size at weaning range of $5.69-7.75$ reported in this study compares favourably with the range of $5.33-7.00$ reported by Ezea et al (2015) but higher than $2.28-4.13$ and $3.65-5.22$ reported by Laxmi et al (2009) and Iheukwumere $(2008)$ respectively. Significant $(P<0.05)$ differences existed in the average litter weight at weaning. The highest was recorded for does on diets $C$ $(791.25 \pm 35.85 \mathrm{~g})$ and $B(781.25 \pm 44.93 \mathrm{~g})$, followed by those on diet $A(607.5 \pm 12.67 \mathrm{~g})$ and those on diet $D$ $(290.0 \pm 10.3 \mathrm{~g})$. 
Table 3: The effect of the treatment diets on the reproductive performance of the does

\begin{tabular}{|c|c|c|c|c|}
\hline Parameters & $A(100: 0)$ & $\begin{array}{l}\text { Diets } \\
\text { B }(50: 50)\end{array}$ & C (25:75) & $D(0: 100)$ \\
\hline Litter size at birth & $6.75^{\mathrm{b}}+0.48$ & $7.75^{a}+0.48$ & $7.25^{b}+0.48$ & $5.75^{c}+0.48$ \\
\hline Average litter weight at birth (g) & $50.0^{\mathrm{b}} \pm 3.54$ & $57.5^{\mathrm{a}} \pm 2.50$ & $55.0^{\mathrm{b}} \pm 2.04$ & $47.5^{\mathrm{c}} \pm 1.44$ \\
\hline Mortality before weaning & $0.5 \pm 0.29$ & 0.0 & $0.5 \pm 0.29$ & $1.0 \pm 1.0$ \\
\hline Litter size at weaning & $6.7 \overline{2}^{\mathrm{b}}+0.63$ & $7.75^{a}+0.48$ & $7.2 \overline{1}^{b}+0.29$ & $5.6 \overline{9}^{c}+1.44$ \\
\hline Average litter weight at weaning(g) & $607.5^{\mathrm{c}} \pm 12.67$ & $781.3^{\mathrm{a}} \pm 44.93$ & $731.3^{\mathrm{b}} \pm 35.85$ & $550.0^{\mathrm{d}} \pm 16.63$ \\
\hline Gestation length & 30 & 31 & 30 & 31 \\
\hline
\end{tabular}

abcdMeans on the same row with different superscript differ significantly $(\mathrm{P}<0.05)$.

\section{CONCLUSION AND RECOMMENDATION}

The productive performance characters of the does on the sole concentrate diet were better in terms of final weight, body weight gain and feed conversion ratio than does on the diets with concentrate and forage mixtures. However, the concentrate - forage mixture diets were cheaper. The performance characters of does on diets $B$ and $\mathrm{C}$ were also good compared to the does on sole concentrate diet. The reproductive performance characters of does on diet $B(50: 50)$ and were the best. Therefore, diet B (50:50) which is the best in terms of reproductive performance, very good in terms of productive performance and relatively cheap is recommended.

\section{REFERENCES}

Abu OA Onifade AA Abanikanda OTF and Obiyan RI (2008). Status and promotional strategies for rabbit production in Nigeria. Management and Economy $9^{\text {th }}$ World Rabbit Congress, June $10-$ 13, 2008, Verona - Italy.

Adeyemo AA Adeyemi OA Ekunseitan OA and Taiwo OS (2013). Effect of concentrate to forage ratio on the performance and haematological parameters of growing rabbits. Global J Biol., Agric. and Hlth Sci. 2(2): $114-118$.

Adeyemo AA Taiwo OS and Adeyemi OA (2014). Performance and carcass characteristics of growing rabbits fed concentrate to forage ratio. Intern. J Modern Plant and Anim. Sci. 2(1): $33-41$.

Effiong OO and Wogar GS (2007). Litter performance traits of rabbits under mixed feeding regime. Proc. $32^{\text {nd }}$ Annual Conference of the Nigerian Society of Animal Production, Calabar, March $18-21$, 2007. Pp: $155-158$.

Ezea J Iwuji TC and Oguike MA (2015). Lactogenic and reproductive potentials of spreading day flower (Commelina diffusa burm. F) and Rock Fig (Ficus ingens Mig) in rabbit does. Global J Anim. Sci. Res. 3(2): $590-597$.

Farinu GO (1994). Effects of feeding a compound diet based on non conventional feedstuffs on growth and carcass characteristics of rabbits. World Rabbit Sci., 2: 123 - 126.
Iheukwumere FC (2008). Effect of mixed feeding regime on litter performance traits of rabbit does. Pakistan J. Nutri 7(4): 594 596.

Iheukwumere FC and Okoli IC (2002). Preliminary studies on raw Napoleona imperialis as feed ingredient on the performance and blood chemistry of weaner rabbits. Trop. Invest., 6: 113-119.

lyeghe - Erakpotobor GF Adeosun YG Sekoni AA and Esievo LO (2008). Reproductive performance of rabbit does on concentrate to forage (Stylosanthes hamata) combinations. Lives. Res. for Rural Dev. 20(11) http://www.Irrd.org//rrd8/4/suc84htm.

Laxmi PJ Gupta BR Prakash MG Ekambaram E and Amareswari P (2009). A study on the performance of fryer rabbits under different systems of rearing. Lives. Res. for Rural Dev., 21(8). http://www.Irrd.org//rrd8/4/suc84htm.

Leng RA (2006). Digestions in the rabbit - a new look at the effects of their feeding and digestive strategies. Workshop - seminar "Forages for pigs and rabbits". MEKARN CelAgrid, Phnon Penh, Cambodia, 22 - 24 August, 2006. Article18. Retrieved December 23, 112, from http://www.mekarn.org/proprl/leng.htm

Linga SS and Lukefahr SD (2000). Feeding of alfalfa hay with molasses blocks or crumbles to growing rabbits fryers. Lives. Res. for rural Dev., 12(4). http://www.cipav.org.co//rrd/lrrd12/4/ling124.htm

Marykutty T and Nandakumar P (2000). Factors influencing litter traits and body weight up to 12 weeks among temperate rabbit breeds in humid tropics. World rabbit Science. 8(2): $67-70$.

Naginene AC and Abdullah OS (1992). Chemical composition of some fodder grass of the dare Saleem. Trop. Agric. (Trinidad), 60 (3): $152-153$.

Nwagu FO Nwagu BI and lyeghe - Erakpotobor GT (2010). Partitioning of protein for growth by rabbits fed groundnut and Stylosanthes forages supplemented with concentrate. Nig. J. Anim. Sci. 12: $93-101$.

Oloruntola OD Daramola OT and Omoniyi SO (2015). Effects of forages on performance, carcass cuts and haematological profile of weaner rabbits. Arch. Zootec. 64(245): 87 - 92.

Ukpe NE Ukpe IE and Ilo SU (2009). Effect of feeding three types of forage on the performance of weaner rabbits. Proceedings of the $14^{\text {th }}$ Annual Conferenc of Animal Science Association of Nigeria (ASAN), LAUTECH, Ogbomoso, Nigeria. Pp. 357 - 358.

Yusuf AM Olafadehan OA and Garba MH (2010). Evaluation of the feeding potentials of Vitellaria paradoxa, Nauclea latifolia and Terminalia macroptera foliage as supplements to concentrate feed for growing rabbits. Aust. J Basic and Appl. Sci. 4(3): $429-$ 433. 